\title{
The Influence Of Co/Sr and Fe/Sr Driers on Film Formation of High Solid Alkyd Coatings
}

\author{
Barbara Pirš, ${ }^{1, *}$ Bogdan Znoj, ${ }^{1}$ Saša Skale, ${ }^{2}$ Jožefa Zabret, ${ }^{1}$ \\ Jerneja Godnjavec, ${ }^{3}$ Peter Berce ${ }^{1}$ and Peter Venturini ${ }^{2}$ \\ ${ }^{1}$ Helios TBLUS, d.o.o., Kolicevo 65, 1230 Domžale, Slovenia. \\ ${ }^{2}$ Helios Domžale d.d., Količevo 2, 1230 Domžale, Slovenia. \\ ${ }^{3}$ Center of Excellence for Polymer Materials and Technologies, Tehnoloski park 24, 1000 Ljubljana, Slovenia. \\ * Corresponding author: E-mail: barbara.pirs2@helios.si
}

Received: 04-06-2014

\begin{abstract}
High solid (HS) alkyd resins with low amount of volatile organic compounds (VOC) were developed as the result of new VOC solvent directive that limit the amount of VOC in decorative paints. Due to specific chemical structure of HS alkyd resins and possible deterioration of some applicative properties the optimal combination of driers is an important subject of research. In our present work we studied the influence of Fe bispidon (Fe drier) and Co ethylhexanoate (Co drier) surface driers with $\mathrm{Sr}$ carboxylate (Sr drier) through drier on the film formation of HS alkyd coatings. The kinetics of autoxidation was analysed using FT-IR spectroscopy. Further, applicative properties like drying time and film hardness were examined. In the end, electrochemical impedance spectroscopy (EIS) was used to evaluate the quality of cured HS alkyd coating films after exposure in the humidity chamber. It was established that the addition of the Sr drier to surface driers accelerates the autoxidation process. As higher amounts of the Sr drier were added, final drying times were reduced and film hardness increased. The lowest diffusivity of ions through cured HS alkyd coating films was observed for $\mathrm{Co} / \mathrm{Sr}$ and $\mathrm{Fe} / \mathrm{Sr}$ drier combination at 1:1 concentration ratio.
\end{abstract}

Keywords: HS alkyd coatings, drier, Sr, FT-IR, EIS

\section{Introduction}

Alkyd coatings are complex mixtures based on alkyd polymers, which have both a decorative and a protective function. The term coating describes a liquid material that is applied to a substrate, after application of which a formed solid coating film results. The formation of a film is a process where physical and chemical changes occur. ${ }^{1,2}$ Chemical changes are the consequence of a free-radical reactions known also as autoxidation. The reactions are usually catalysed using a combination of organic metal salts known as driers. Driers are typically classified by function as surface, through and auxiliary driers. ${ }^{3,4}$ Surface driers exert a catalytic effect and accelerate surface drying. Through driers promote curing beneath the surface of the coating and improve the stability of the surface driers. They form oxygen-metal-oxygen crosslinks by reacting hydroxyl and carboxyl groups with polymer molecules, which contribute to the through-drying process. ${ }^{4,5}$ Auxiliary driers inhibit phase separation from the coating surface. ${ }^{4}$ To assure optimal film formation, coatings usually contain a mixture of all three types of driers. ${ }^{5}$ The amount of driers needed is system specific and should be kept to the minimum possible level. ${ }^{3,6}$

Alkyd polymers are used in alkyd coating formulations due to their low cost and versatility. They belong to a group of environmentally friendly resins whereas most of the constituents belong to renewable raw materials, except for phthalic anhydride which is of petrochemical origin. ${ }^{7}$ Recently HS alkyd resins with reduced contents of organic solvent were developed in the face of new requirements in EU environmental legislation. ${ }^{1,2}$ The introduction of new or modified polymers is often associated with the deterioration of several applicative and performance coating properties. In the case of HS alkyd coatings, deterioration exhibits as poorer drying performance. This is manifested 
in prolonged Set-to-Touch Times, poor Through Drying, and as a consequence lower film hardness. ${ }^{7}$ For this reason most research until now has been focused on the testing of alternative surface dryers and combination with through driers. ${ }^{8}$ It has been found that drier combinations in HS alkyd resins behave differently than in conventional alkyd resins. ${ }^{1}$ Hein R.W for HS coatings has recommended that concentration levels of the through drier should be increased. Further, he suggested avoiding the combination $\mathrm{Co} / \mathrm{Ca}$ driers due to Ca's promotion of Co activity and the resulting premature top drying. He also proposed the use of through driers neodymium $(\mathrm{Nd})$ and aluminium $(\mathrm{Al})$ since they exhibit better performance in HS coatings than zirconium ( $\mathrm{Zr}){ }^{7}$ Muizebelt W. J. et. al. determined that the addition of $\mathrm{Al}$ complexes in $\mathrm{HS}$ alkyd coatings provides enhanced drying, grater hardness and better gloss; on the downside, however, the coatings become brittle when exposed outdoor weathering. ${ }^{8}$ Hein R. W. indicates a combination of $\mathrm{Co} / \mathrm{Nd}^{+}$bipyridine (bpy) as the best combination of HS alkyd resins. ${ }^{1}$

Interesting catalytic properties can also be observed with $\mathrm{Fe}$ surface drier. It reacts on the surface and through the coating, which makes it interesting for use in HS alkyd coatings. ${ }^{9}$

In our work we made a comparative study of the influence of $\mathrm{Fe} / \mathrm{Sr}$ and $\mathrm{Co} / \mathrm{Sr}$ driers on the autoxidation curing process of HS alkyd coatings. Later we evaluate drying performance, hardness and finally the characteristics of cured coating film by EIS.

\section{Experimental}

\section{1. Materials and Sample Preparation}

We used the following components in the preparation of coatings: resin, driers, anti-skinning agents and a solvent. Synolac 4047 WD 90, a long oil alkyd resin with low VOC was used as a resin, supplied by Cray Valley (90 wt. \% of solid content based on orto-phthalic acid anhydride, polyol-pentaerythritol and linoleic rich fatty acids).

As driers we used a commercially available Fe drier (Fe bispidon) (Figure 1), supplied by OMG (Borchi Oxy Coat with 1 wt. \% of Fe complex in 1,2-propylene glycol) and a commercially available Co drier also obtained from OMG (Co bis (2-ethylhexanoate) with $10 \mathrm{wt}$ \% of Co).

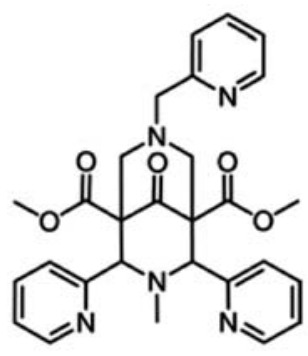

Figure 1. Ligand bispidon. ${ }^{9}$
As a through drier we used a $\mathrm{Sr}$ drier ( $\mathrm{Sr}$ carboxylate with $18 \%$ Sr) supplied by ROCKWOOD.

An anti-skinning agent (Methyl Ethyl Ketoxime MEKO) was added to prevent the skinning of coatings in closed containers.

Samples were prepared by adding individual components (driers, anti-skinning agent and solvent) to an alkyd resin and mixed with a propeller stirrer for 10 minutes at room temperature. The amount of used resin was 83 wt. \%. The addition of MEKO was 0.7 wt. \%. The rest of the mixture consisted of non-aromatic solvent Shellsol D-40 that was added to adjust the viscosity of the coating between $0.7-1.0$ Pas.

Surface driers were added in accordance with producer recommendations. Therefore we used $0.78 \mathrm{wt} . \%$ of Fe drier and 1 wt. $\%$ of Co drier on resin solid content. A Sr through drier was added in three different ratios (1:1, 1:3.5 and 1:10) to the Co and Fe driers. Tests were performed after 24 hours of sample storage. The sample names are composed from the combination of surface/through drier and their ratio (e.g. Fe/Sr (1:3.5).

\section{2. Analytical Methods}

The influence of Co and Fe driers on HS alkyd coating characteristics was analysed by different analytical methods.

Time-resolved FT-IR spectra were obtained using a Thermo Nicolet 6700 spectrometer and the transmission technique (KBr crystal, range $400-4000 \mathrm{~cm}^{-1}$, resolution $4 \mathrm{~cm}^{-1}$ ). Coating samples were applied on a $\mathrm{KBr}$ crystal plate with $7 \mu \mathrm{m}$ spiral film applicator. A FT-IR spectrum was measured every 30 minutes. In the meantime samples were placed in the conditioner at $23{ }^{\circ} \mathrm{C}$ and $50 \%$ humidity. We monitored the peaks at $3007 \mathrm{~cm}^{-1}$ ( cis-C=C-H stretching) and $3450 \mathrm{~cm}^{-1}$ (-O-H stretching) normalized against the ester peak at $1272 \mathrm{~cm}^{-1}$ (-COOC stretching) versus time. Relative reaction rates of radical initiated crosslinking were calculated after the induction period with a linear regression as $\ln \left(\mathrm{A}_{\mathrm{t}} / \mathrm{A}_{0} * 100\right)$ versus time.

Drying performance was determined by BYK drying recorder according to ASTM D5895-03. Coating samples were applied to plain glass of approx. $60 \mu \mathrm{m}$ wet film thickness. The instrument included needles that travel on the plain glass with coating test strip within a chosen range of time - in our case $6 \mathrm{~h}$. Different trace formations on the coating film were evaluated to define different stages of the film formation process.

To determine hardness of a coating surface film the standard König method was used according to ISO 1522. Coating samples were applied to plate glass with an applicator (wet film thickness of $60 \mu \mathrm{m}$ ). Successive measurements were taken after 1, 3, 7, 14, 21 and 28 days of drying. The results were determined as glass standard hardness and expressed as relative hardness.

Electrochemical impedance spectroscopy (EIS) is an established quantitative method for anticorrosion ex- 
amination of coating films. In our research we used EIS to evaluate the quality of the HS alkyd coatings after curing process with different combinations of driers. Coating samples were applied on metal plates by spraying in three layers over three consecutive days. The final cured film thickness was measured with an Elcometer 456 (F1 magnetic induction probe from Elcometer Ltd.) and average determined values were between $72 \mu \mathrm{m}$ and $88 \mu \mathrm{m}$. For each sample 15 measurements were taken in compliance with the ISO 2178 standard. Prepared samples remained in the conditioner for 5 days at $23{ }^{\circ} \mathrm{C}$ and $50 \%$ humidity. The samples were then placed in humidity chamber Ericssen HIGROTHERUS 519 for $4 \mathrm{~h}$ ( $\mathrm{T}$ was $40 \pm 0.5^{\circ} \mathrm{C}$ and relative humidity was maintained at $95 \pm 0.5 \%$ ) after which they were measured by EIS. All EIS measurements were carried out in duplicate.

EIS measurements were performed using a Parstat 2273 potenciostat. The measuring cell was a standard three-electrode Tait-cell, consisting of a working electrode of $32 \mathrm{~cm}^{2}$ immersed in $0.1 \mathrm{M} \mathrm{NaCl}$ solution, a Hastelloy counter electrode and a standard calomel reference electrode (SCE). The potential difference between the working and counter electrode was $-0.6 \mathrm{~V}$ versus SCE with signal amplitude of $30 \mathrm{mV}$. Data were collected and analysed using Electrochemistry Power Suite and PowerSINE software (Princeton Applied Research, USA). Impedance spectra analysis was performed after numerical fitting using an equivalent electrical circuit, presented in Figure 2.

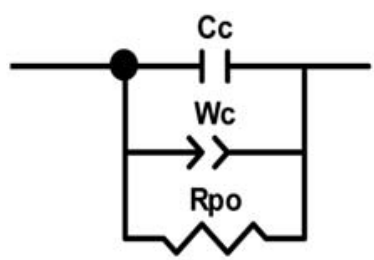

Figure 2. Assumed equivalent electrical circuit for HS alkyd coatings with different drier combinations.

\section{Results and Discussion}

\section{1. Time Resolved FT-IR Experiment: Evaluation of Chemical Curing}

Chemical curing of HS alkyd coatings as a part of film formation process was monitored by FT-IR spectroscopy. From the FT-IR spectra of HS alkyd coating shown in Fig. 3 we can observe different band assignments that belong to chemical groups or bonds. ${ }^{9}$ Our research was focused on peaks at $3450 \mathrm{~cm}^{-1}, 3007 \mathrm{~cm}^{-1} 987$ $\mathrm{cm}^{-1}, 970 \mathrm{~cm}^{-1}$ and $948 \mathrm{~cm}^{-1}$, which were changing during the autoxidation curing process of HS alkyd coatings .

Generally, autoxidation is a process in which atmospheric oxygen reacts with double bonds of unsaturated

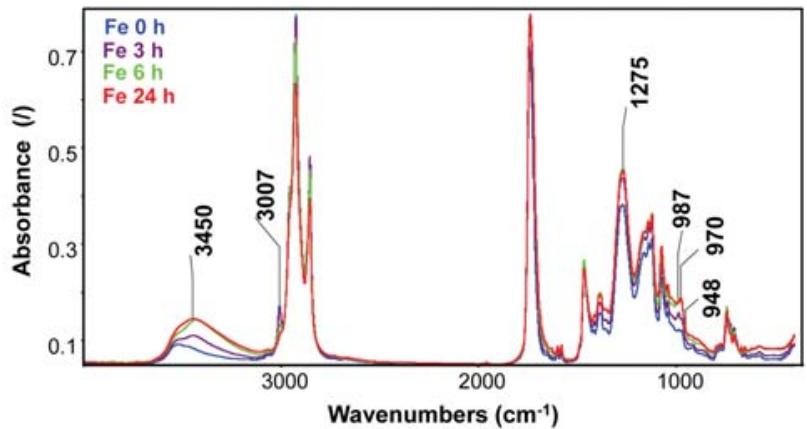

Figure 3. FT-IR spectra of HS alkyd coatings with Fe surface driers versus time.

fatty acid from alkyd resins. ${ }^{1,3}$ The reactions of autoxidative curing process can be seen from Fig. 4. Important chemical changes are related to unsaturated double bonds. We used HS alkyd resin with linoleic acid that contain isolated cis double bonds what can be seen in FT-IR spectra from band at $3007 \mathrm{~cm}^{-1}$ (cis- $\mathrm{C}=\mathrm{C}-\mathrm{H}$ stretching).

Film formation of alkyd coatings starts with an induction period where evaporation of solvent and oxygen absorption takes place. Further delocalization of isolated cis double bonds occurs due to hydrogen abstraction, which induces the reaction with oxygen and the formation of hydroperoxides (-OH band at $\left.3450 \mathrm{~cm}^{-1}\right)$. During the reaction isolated cis double bonds (band at $3007 \mathrm{~cm}^{-1}$ ) transform to conjugated trans double bonds (band at 987 $\mathrm{cm}^{-1}$ and $948 \mathrm{~cm}^{-1}$ ). Hydroperoxides (band at $3450 \mathrm{~cm}^{-1}$ ) then decompose into alkoxy and hydroxy radicals. ${ }^{9}$ Crosslinking reactions further occur when conjugated trans double bonds transform to isolated trans double bonds (band at $\sim 970 \mathrm{~cm}^{-1}$ ). During the process intermolecular linkages are formed, which lead to a network formation and increased viscosity. Byproducts of decomposition like aldehydes, ketones and carboxylic acids are also formed by side reactions. $3,4,9,16$

In our study of HS alkyd curing it was initially observed that surface driers have significant influence on formation of hydroperoxides what is evident from - $\mathrm{OH}$ group changes (Fig. 5). However, $-\mathrm{OH}$ groups are present also in the coating from the start of curing because the driers are diluted in different alcohol-based solvents. In order to evaluate the formation of hydroperoxide during the autoxidation process the $-\mathrm{OH}$ groups from solvents were considered as the initial value of $-\mathrm{OH}$ group in Equation 1:

$$
\begin{aligned}
\left(A_{t}-\right. & \left.A_{t=0}\right) / A_{0} \\
A_{t}= & \text { area of }-\mathrm{OH} \text { groups versus time } \\
& \left(\text { band at } 3450 \mathrm{~cm}^{-1}\right) \\
A_{t=0}= & \text { initial value of area of }-\mathrm{OH} \\
& \text { groups (band at } \left.3450 \mathrm{~cm}^{-1}\right) \\
A_{0}= & \text { normalized peak (band at } 1272 \mathrm{~cm}^{-1} \text { ) }
\end{aligned}
$$




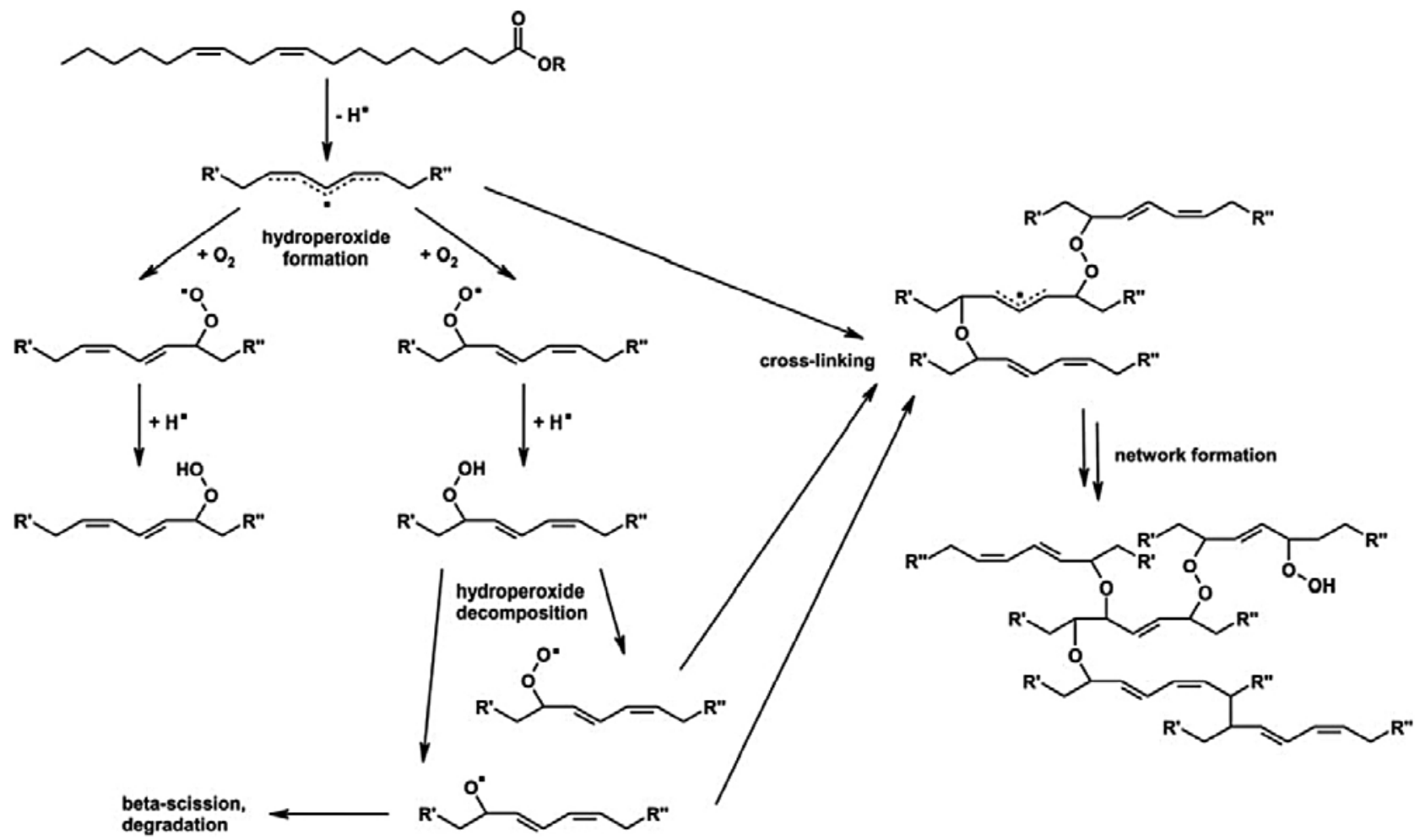

Figure 4. Shematic presentation of the autooxidative curing process in alkyd coatings. ${ }^{9,16}$

The most intensive formation of hydroperoxides was observed for HS alkyd coatings with Co drier, what can be attributed to higher catalytic activity of Co. ${ }^{4,6}$ The diffusion of oxygen in the coating film start at the end of the induction period and declines with the outset of coating film solidification (Fig. 5) ${ }^{21}$ In all tested samples hydroperoxides start to form after induction time. Once the formation of hydroperoxide ends the coating surface solidifies and the concentration of $-\mathrm{OH}$ groups remain constant.

When using surface driers alone, the HS alkyd samples achieve higher hydroperoxide concentrations in com-

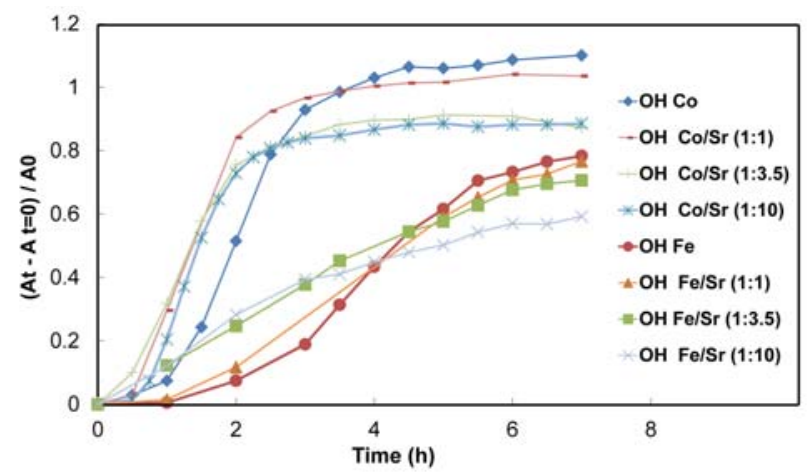

Figure 5. Monitoring of -OH group (band at $3450 \mathrm{~cm}^{-1}$ ) during autoxidation process of $\mathrm{HS}$ alkyd coatings with different drier combinations. parison with $\mathrm{Co} / \mathrm{Sr}$ and $\mathrm{Fe} / \mathrm{Sr}$ drier combinations. Higher $\mathrm{Sr}$ drier ratios result in less hydroperoxide formation. With $\mathrm{Co} / \mathrm{Sr}$ and $\mathrm{Fe} / \mathrm{Sr}$ drier combinations hydroperoxides start to decompose earlier and faster than in cases using only surface driers. $\mathrm{Co} / \mathrm{Sr}$ drier combinations exhibit faster hydroperoxide decomposition than $\mathrm{Fe} / \mathrm{Sr}$ drier combinations.

The chemical curing of HS alkyd coatings was further analysed from transformation of cis- $\mathrm{C}=\mathrm{C}-\mathrm{H}$ double bonds (band at $3007 \mathrm{~cm}^{-1}$ ). ${ }^{10,22,23}$ FT-IR spectra of HS alkyd coatings were recorded after different times. Relative reaction rates have been calculated with linear regression of the $\ln \left(\mathrm{A}_{\mathrm{t}} / \mathrm{A}_{0} * 100\right)$ versus time after the induction period. The changes during chemical curing of HS alkyd coatings are quantitatively presented in Table 1.

Induction time is the period during which the peak at $3007 \mathrm{~cm}^{-1}$ remains unchanged. ${ }^{21}$ For samples with only surface Co driers induction times lasted $\approx 1 \mathrm{~h}$ and for surface $\mathrm{Fe}$ drier $\approx 3 \mathrm{~h}$. With the addition of a $\mathrm{Sr}$ drier induction times were reduced considerably (Table 1).

Relative reaction rates were higher with Co than with $\mathrm{Fe}$ surface drier. The addition of $\mathrm{Sr}$ to the Co drier increases the reaction rate. An adverse effect of $\mathrm{Sr}$ drier was observed in combination with a $\mathrm{Fe}$ drier, where reaction rates were similar to the samples with only $\mathrm{Fe}$ drier. However in the case of $\mathrm{Fe} / \mathrm{Sr}$ (1:10) driers the reaction rate slows down considerably. 
Table 1. FT-IR related data.

\begin{tabular}{lcccc}
\hline $\begin{array}{l}\text { Coating } \\
\text { samples }\end{array}$ & $\begin{array}{c}\text { Induction time } \\
(\mathbf{h})\end{array}$ & $\begin{array}{c}\text { Reaction rate } \mathbf{h}^{\mathbf{- 1}} \text { ) } \\
\text { (Isolated cis- } \\
\text { double bonds) }\end{array}$ & $\begin{array}{c}\text { Increase of } \\
\text { conjugated trans- } \\
\text { double bonds (h) }\end{array}$ & $\begin{array}{c}\text { Increase of } \\
\text { isolated trans- } \\
\text { double bonds (h) }\end{array}$ \\
\hline $\mathrm{Co}$ & $1.0 \pm 0.3$ & $1.039 \pm 0.051$ & $2.5 \pm 0.3$ & $3 \pm 0.3$ \\
$\mathrm{Co} / \mathrm{Sr}(1: 1)$ & $0.5 \pm 0.3$ & $1.123 \pm 0.029$ & $2.0 \pm 0.3$ & $2.75-3 \pm 0.3$ \\
$\mathrm{Co} / \mathrm{Sr}(1: 3.5)$ & $0.5 \pm 0.3$ & $1.156 \pm 0.043$ & $1.5 \pm 0.3$ & $2.5-2.75 \pm 0.3$ \\
$\mathrm{Co} / \mathrm{Sr}(1: 10)$ & $0.5 \pm 0.3$ & $1.178 \pm 0.026$ & $1.5 \pm 0.3$ & $2.5 \pm 0.3$ \\
$\mathrm{Fe}$ & $3.0 \pm 0.3$ & $0.272 \pm 0.015$ & $5.0 \pm 0.3$ & $>7 \pm 0.3$ \\
$\mathrm{Fe} / \mathrm{Sr}(1: 1)$ & $2.0 \pm 0.3$ & $0.275 \pm 0.009$ & $5.0 \pm 0.3$ & $>7 \pm 0.3$ \\
$\mathrm{Fe} / \mathrm{Sr}(1: 3.5)$ & $2.0 \pm 0.3$ & $0.267 \pm 0.003$ & $4.5 \pm 0.3$ & $>7 \pm 0.3$ \\
$\mathrm{Fe} / \mathrm{Sr}(1: 10)$ & $2.0 \pm 0.3$ & $0.174 \pm 0.005$ & $5.5-6.5 \pm 0.3$ & $>7 \pm 0.3$ \\
\hline
\end{tabular}

Further chemical changes due to the autoxidation mechanism can be traced along the FT-IR peaks of conjugated trans $-\mathrm{C}=\mathrm{C}-\mathrm{H}$ double bonds and isolated trans $-\mathrm{C}=\mathrm{C}-$ $\mathrm{H}$ double bonds. The band of conjugated trans $-\mathrm{C}=\mathrm{C}-\mathrm{H}$ double bonds (at $987 \mathrm{~cm}^{-1}$ and $948 \mathrm{~cm}^{-1}$ ) increases for a few hours, after which it starts to decrease. However, isolated trans- $\mathrm{C}=\mathrm{C}-\mathrm{H}$ increases over the entire chemical curing process, what indicates that crosslinking is taking place (Fig. 6). ${ }^{9}$

Faster conversion of conjugated to isolated trans$\mathrm{C}=\mathrm{C}-\mathrm{H}$ double bonds can be observed (Table 1 ) by addi-

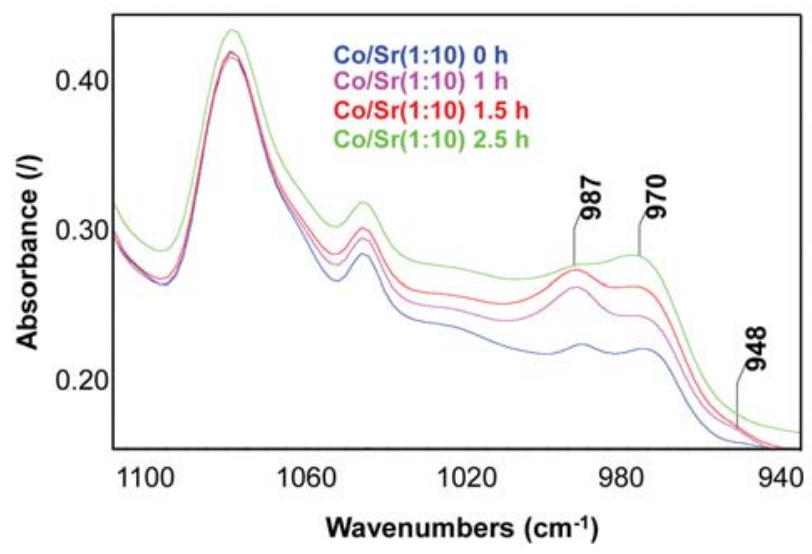

Figure 6. Detailed and shifted FT-IR spectra of HS alkyd coatings with $\mathrm{Co} / \mathrm{Sr}(1: 10)$ drier- combinations versus time. tion of Sr drier to the Co drier. On the other hand the starting times for formation of conjugated and isolated trans$\mathrm{C}=\mathrm{C}-\mathrm{H}$ double bonds are similar for HS alkyd coatings with $\mathrm{Fe} / \mathrm{Sr}$ drier combinations. The only exception is the combination of driers $\mathrm{Fe} / \mathrm{Sr}$ (1:10) where the formation of conjugated and isolated trans $-\mathrm{C}=\mathrm{C}-\mathrm{H}$ double bonds was starting later.

It was also seen that isolated trans- $\mathrm{C}=\mathrm{C}-\mathrm{H}$ bonds increase after the induction period what can be a consequence of crosslinking via direct addition of radicals to double bonds according to Oyman. ${ }^{3}$

From these results we can confirm that the addition of $\mathrm{Sr}$ as a through drier reduces induction time and accelerates the autoxidation process.

\section{2. Drying Time}

Drying time is a process of different drying stages by which we monitor transformation of the applied liquid coating into a solid coating film. ${ }^{1}$ Drying performance of HS alkyd coatings was determined using a BYK drying recorder according to ASTM D5895-03..$^{24}$ In our case we focused on Set-to-Touch Time and Final Drying Time stages. The results are presented in Table 2.

Set-to-Touch Times decreases with the increased ratio of $\mathrm{Sr}$ through drier compared to the HS alkyd coatings where only a surface drier was used (Table 2). $\mathrm{Co} / \mathrm{Sr}$ and $\mathrm{Fe} / \mathrm{Sr}$ (1:10 ratio) drier combinations exhibited the short-

Table 2. Set-to-Touch Time, Final Drying Time values and Relative film coating hardness after 28 days for HS alkyd coatings using different drier combinations.

\begin{tabular}{lccc}
\hline $\begin{array}{l}\text { Coating } \\
\text { samples }\end{array}$ & $\begin{array}{c}\text { Set-to-Touch Time } \\
\text { (h) }\end{array}$ & $\begin{array}{c}\text { Final Drying Time } \\
\text { (h) }\end{array}$ & $\begin{array}{c}\text { Film hardness after } \\
\mathbf{2 8} \text { days (\%) }\end{array}$ \\
\hline $\mathrm{Co}$ & $2.7 \pm 0.2$ & $>6 \pm 0.2$ & $104 \pm 3$ \\
$\mathrm{Co} / \mathrm{Sr}(1: 1)$ & $2.7 \pm 0.2$ & $5.8 \pm 0.2$ & $132 \pm 3$ \\
$\mathrm{Co} / \mathrm{Sr}(1: 3.5)$ & $1.6 \pm 0.2$ & $5.1 \pm 0.2$ & $137 \pm 3$ \\
$\mathrm{Co} / \mathrm{Sr}(1: 10)$ & $1.2 \pm 0.2$ & $4.7 \pm 0.2$ & $150 \pm 3$ \\
$\mathrm{Fe}$ & $3.5 \pm 0.2$ & $5.5 \pm 0.2$ & $45 \pm 3$ \\
$\mathrm{Fe} / \mathrm{Sr}(1: 1)$ & $2.6 \pm 0.2$ & $4.3 \pm 0.2$ & $46 \pm 3$ \\
$\mathrm{Fe} / \mathrm{Sr}(1: 3.5)$ & $1.5 \pm 0.2$ & $4.3 \pm 0.2$ & $49 \pm 3$ \\
$\mathrm{Fe} / \mathrm{Sr}(1: 10)$ & $1.1 \pm 0.2$ & $3.8 \pm 0.2$ & $67 \pm 3$ \\
\hline
\end{tabular}


est Set-to-Touch Times. Final Drying Times were reduced with the addition of a Sr through drier. The shortest Final Drying Times were observed for $\mathrm{Fe} / \mathrm{Sr}(1: 10)$ combination. Due to reduced curing rate, we assume that the faster drying time was a consequence of faster skin layer growth. ${ }^{19}$

\section{3. Hardness}

Hardness values for HS alkyd coatings were measured by König method that evaluates the surface hardness of dried coating film. Higher $\mathrm{Sr}$ concentration in combination with surface driers enables higher hardness values of coatings than those using only surface driers (Table 2). Hardness values for the samples with Co drier combinations were significantly higher than with $\mathrm{Fe}$ drier. Boer at. al. in his paper stated reduction in hardness, in case of use $\mathrm{Fe}$-bispidon drier in $\mathrm{HS}$ alkyds. The addition of a $\mathrm{Sr}$ drier improves film hardness in combination with a Co drier. However, in combination with a Fe drier has less impact on surface film hardness.

The differences between $\mathrm{Co} / \mathrm{Sr}$ and $\mathrm{Fe} / \mathrm{Sr}$ drier combinations are due to differences of surface drier activity. In the literature it was confirmed that Co drier does not crosslink homogeneously along the depth of an alkyd film due to the very high catalytic activity on the surfaces. ${ }^{3}$ For Fe drier it is also known, that poses through drying effect. ${ }^{4}$

Electrochemical impedance spectroscopy (EIS)

In order to evaluate the influence of different $\mathrm{Co} / \mathrm{Sr}$ and $\mathrm{Fe} / \mathrm{Sr}$ drier combinations on curing of HS alkyd coatings, impedance spectra of dried coating films were measured after exposure in the humidity chamber. A Nyquist plot of impedance spectra along with fitting curves is displayed in Fig. 7. By comparing the inclination and the shape of the impedance curves it can be concluded that the addition of Sr drier generally has an adverse effect on barrier properties of the coatings as determined by EIS. However, by examining individual elements of the equivalent circuit a more profound understanding of Sr drier influence on coating properties can be attained.

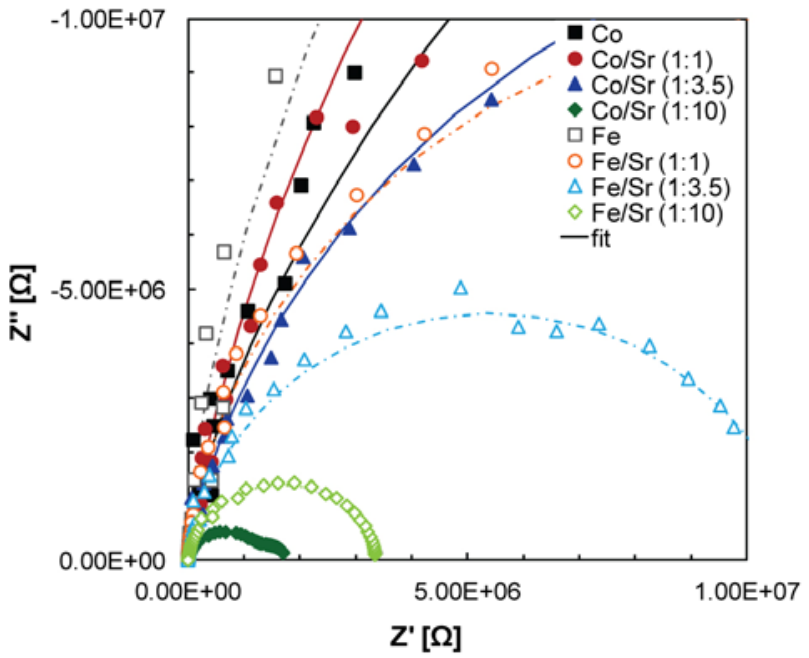

Figure 7. Nyquist plot of EIS measurements and equivalent circuit model for HS alkyd coatings of different drier combinations.

In order to reduce the effect of coating thickness variation, characteristic properties of the equivalent circuit elements were converted to thickness independent quantities. Coating capacitance, Warburg coefficient, pore resistance and coating thickness were thus used to obtain dielectric constant $\varepsilon_{\mathrm{c}}$, the product of Warburg diffusion coefficient with film thickness $\sigma_{c} \cdot d_{c}$ and specific pore resistance $\rho_{\mathrm{po}}{ }^{25}$ Results are presented in Table 3.

Exposure in the humidity chamber resulted in an increase of the dielectric constants for all coating samples, which is an indication of water absorption. ${ }^{25}$ Dielectric constants can be used to estimate the amount of absorbed water. ${ }^{26}$ In the case of investigated samples water absorption was estimated to be about 1-2 vol \%. Larger increases were observed in samples which contained only surface $\mathrm{Fe}$ and Co driers. Samples with $\mathrm{Fe} / \mathrm{Sr}$ drier combinations displayed lower values of dielectric constants than samples with $\mathrm{Co} / \mathrm{Sr}$ combinations (Table 3).

Table 3. EIS parameters after $4 \mathrm{~h}$ after exposure in the humidity chamber.

\begin{tabular}{lccc}
\hline $\begin{array}{l}\text { Coating } \\
\text { samples }\end{array}$ & $\varepsilon_{\mathbf{c}}(/)$ & $\left(\mathbf{1 0}^{-\mathbf{6}} \mathbf{\Omega}^{-\mathbf{1}} \mathbf{r a d}_{\mathbf{c}}^{* \mathbf{1} / \mathbf{2}} \mathbf{s}^{\mathbf{1 / 2}} \boldsymbol{\mu \mathbf { m } )}\right.$ & $\begin{array}{c}\boldsymbol{\rho}_{\mathbf{p o}} \\
\left(\mathbf{1 0} \mathbf{\Omega}^{\mathbf{2}} \boldsymbol{\mu \mathbf { m }}\right)\end{array}$ \\
\hline $\mathrm{Co}$ & $7.1 \pm 0.3$ & $0.95 \pm 0.08$ & $2669 \pm 249$ \\
$\mathrm{Co} / \mathrm{Sr}(1: 1)$ & $6.3 \pm 0.3$ & $0.41 \pm 0.03$ & $763 \pm 53$ \\
$\mathrm{Co} / \mathrm{Sr}(1: 3.5)$ & $6.0 \pm 0.2$ & $0.57 \pm 0.03$ & $328 \pm 16$ \\
$\mathrm{Co} / \mathrm{Sr}(1: 10)$ & $6.3 \pm 0.5$ & $19.11 \pm 2.02$ & $16 \pm 1$ \\
$\mathrm{Fe}$ & $7.2 \pm 0.4$ & $0.35 \pm 0.05$ & $1551 \pm 267$ \\
$\mathrm{Fe} / \mathrm{Sr}(1: 1)$ & $4.5 \pm 0.3$ & $0.19 \pm 0.02$ & $357 \pm 24$ \\
$\mathrm{Fe} / \mathrm{Sr}(1: 3.5)$ & $4.6 \pm 0.2$ & $0.30 \pm 0.02$ & $184 \pm 7$ \\
$\mathrm{Fe} / \mathrm{Sr}(1: 10)$ & $4.6 \pm 0.2$ & $0.51 \pm 0.02$ & $55 \pm 2$ \\
\hline
\end{tabular}

${ }_{*} \varepsilon_{\mathrm{c}}=$ relative dielectric constant, $\sigma_{\mathrm{c}^{*}} \mathrm{~d}_{\mathrm{c}}=$ product of Warburg coefficient and film tickness, $\rho_{\mathrm{po}}=$ pore resistance 
The product $\sigma_{c} \cdot d_{c}$ represents diffusion of ions of the supporting electrolyte through the coating film. Higher values of $\sigma_{c} \cdot d_{c}$ correspond to higher diffusivity of ions through the polymer matrix. ${ }^{27}$ Differences in Warburg diffusion were observed between coatings with different drier combinations (Table 3). The addition of $\mathrm{Sr}$ through drier to surface driers at ration 1:1 induces lower diffusivity of ions through the cured coating film however further increase of $\mathrm{Sr}$ through drier result in increased Warburg diffusion. The lowest diffusivity of ions was determined also for Fe drier what can be explained by homogeneous crosslinking through the depth of the coating film. ${ }^{28}$ Pore resistance comparison shows that higher concentrations of $\mathrm{Sr}$ through drier correspond to higher film porosity.

\section{Conclusions}

HS alkyd resins have specific chemical structures that influence also on physical and chemical changes of HS alkyd coatings during curing process; however, they can be optimised with the combination of surface and through driers. In our case we studied $\mathrm{Co}$ and $\mathrm{Fe}$ surface driers in combination with a Sr through drier and their impact on alkyd coating film formation properties.

Chemical changes in HS alkyd coatings were observed by FT-IR according to the autoxidation mechanism. Due to changes in FT-IR spectra it was established that the formation of hydroperoxides is slower in HS coatings with $\mathrm{Fe}$ surface drier compared to Co surface driers. The addition of a $\mathrm{Sr}$ through drier increases the decomposition of hydroperoxides in combination with both surface driers. Similar behaviour was also observed by comparing induction drying times. Further we established that the transformation of $c i s-\mathrm{C}=\mathrm{C}-\mathrm{H}$ double bond was higher in HS coatings with Co drier combinations. Sr through drier in combination with a Co surface drier increases the transformation reaction rates. The same behaviour was observed with higher ratio of $\mathrm{Sr}$ through drier. On the other side, lower concentrations of $\mathrm{Sr}$ through drier in combination with Fe drier did not have significant effect on transformation of $c i s-\mathrm{C}=\mathrm{C}-\mathrm{H}$ reaction rates. The exception is only $\mathrm{Fe} / \mathrm{Sr}(1: 10)$ combination where important decrease of transformation reaction rate was observed.

In terms of physical changes higher values of König hardness were determined for HS alkyd coatings with a Co surface drier compared to Fe surface driers. The addition of a Sr through drier increases hardness values and reduces film formation drying times.

Cured coating film characteristics were finally evaluated by comparing EIS overall equivalent circuit parameters. HS alkyd samples with $\mathrm{Co} / \mathrm{Sr}$ and $\mathrm{Fe} / \mathrm{Sr}$ drier combinations exhibited comparable water absorption levels. Low ratio of Sr driers to surface driers decreases the diffusion of ions through the coating film. The lowest diffusion of ions was achieved with 1:1 ratio of $\mathrm{Fe} / \mathrm{Sr}$ driers, which confirm higher through drying activity of Fe drier. All measured samples developed pores.

\section{Acknowledgements}

"Operation part financed by the European Union, European Social Found. Operation implemented in the framework of the Operational Program for Human Resources Development for the Period 2007-2013, Priority axis 1: Promoting entrepreneurship and adaptability, Main type of activity 1.1: Experts and researchers for competitive enterprises."

\section{References}

1. Z. W. Wicks Jr., F. N. Jones, S. P. Pappas, D. A. Wicks, Organic coatings: Science and technology, 3 rd. WileyInterscience, Hoboken, New Jersey, 2007. http://dx.doi.org/10.1002/047007907X

2. A. Overbeek, F. Bückmann, E. Martin, P. Steenwinkel, T. Annable, Prog. Org. Coat. 2003, 48, 125-139. http://dx.doi.org/10.1016/S0300-9440(03)00101-2

3. Z. O. Oyman, $\mathrm{PhD}$ thesis, Technische Universiteit Eindhoven, Eindhoven, Netherlands, 2005.

4. M. D. Soucek, T. Khattab, J. Wu, Prog. Org. Coat. 2012, 73, 435-454.

http://dx.doi.org/10.1016/j.porgcoat.2011.08.021

5. R.W. Hein, J. Coat. Technol. Res. 1998, 70 (886), 19-22. http://dx.doi.org/10.1007/BF02697848

6. J. Lindeboom, Prog. Org. Coat. 1998, 34, 147-151. http://dx.doi.org/10.1016/S0300-9440(98)00034-4

7. A. Hofland, Prog. Org. Coat. 2012, 73, 274-282. http://dx.doi.org/10.1016/j.porgcoat.2011.01.014

8. C. Pilemand, E. Wallström, P. B. Poulsen, Eur. coat. 2005, 2, $7-20$.

9. J. W. de Boer, P. V. Wesenhagen, E. C. M. Wenker, K. Maaijen, F. Gol, H. Gibbs, R. Hage, Eur. J. Inorg. Chem. 2013, 3581-3591. http://dx.doi.org/10.1002/ejic.201300205

10. Z. Liu, H. Kooijman, A. L. Spek, E. Bouwman, Prog. Org. Coat. 2007, 60, 343-349. http://dx.doi.org/10.1016/j.porgcoat.2007.08.003

11. S. T. Warzeska, M. Zonneveld, R. Van Gorkum, W. J. Muizebelt, E. Bouwman, J. Reedijk, Prog. Org. Coat. 2002, 44, 243-248. http://dx.doi.org/10.1016/S0300-9440(02)00057-7

12. J. Z. Wu, E. Bouwman, J. Reedijk, Prog. Org. Coat. 2004, 49, 103-108. http://dx.doi.org/10.1016/j.porgcoat.2003.08.019

13. M. Erben, D. Veselý, J. Vinklárek, J. Honzíček, J. Mol. Catal. A: Chem. 2012, 353-354 13-21. http://dx.doi.org/10.1016/j.molcata.2011.10.024

14. V. Stava, M. Erben, D. Vesely, P. Kalenda, J. Phys. Chem. 
Solids. 2007, 68, 799-802.

http://dx.doi.org/10.1016/j.jpcs.2006.11.019

15. O. Preininger, J. Honzíček, J. Vinklárek, M. Erben, Prog. Org. Coat. 2014, 77, 292-297.

http://dx.doi.org/10.1016/j.porgcoat.2013.10.001

16. R. Van Gorkum, E. Bouwman, Coord. Chem. Rev. 2005, 249, 1709-1728.

http://dx.doi.org/10.1016/j.ccr.2005.02.002

17. R.W. Hein, J. Coat. Technol. Res. 1999, 71(898), 21-25. http://dx.doi.org/10.1007/BF02698429

18. W. J. Muizebelt, J. C. Hubert, R. A. M. Venderbosch, A. J. H. Lansberger, R. P. Klaasen, K. H. Zabel, J. Coat. Technol. Res.1998, 70 (882), 53-59. http://dx.doi.org/10.1007/BF02720515

19. S. J. F. Erich, $\mathrm{PhD}$ thesis, Technische Universiteit Eindhoven, Eindhoven, Netherlands, 2006.

20. S. M. P. Meneghetti, R. F. de Souza, A. L. Monteiro, M.O de Souza, Prog. Org. Coat. 1998, 33, 219-224. http://dx.doi.org/10.1016/S0300-9440(98)00058-7

21. P. Mischke, Film Formation in Modern Paint Systems, Vincentz, Hannover, Germany, 2010.
22. G. Ye, F.Courtecuisse, X. Allonas, C. Ley, C. CroutxeBarghorn, P. Raja, P. Taylor, G. Bescond, Prog. Org. Coat. 2012, 73, 366-373. http://dx.doi.org/10.1016/j.porgcoat.2011.03.015

23. E. Bouwman, R. Van Gorkum, J. Coat. Technol. Res. 2007, 4 (4), 491-503. http://dx.doi.org/10.1007/s11998-007-9041-0

24. ASTM international, Standard test methods for evaluating drying or curing during film formation of organic coatings using mechanical recorders, Designation: D 5895 - 03, 1-4.

25. S. Skale, V. Doleček, M. Slemnik, Prog. Org. Coat. 2008, 62, 387-392. http://dx.doi.org/10.1016/j.porgcoat.2008.02.003

26. A.S. Castela, A.M. Simoes, Corros. Sci. 2003, 45, 16311646. http://dx.doi.org/10.1016/S0010-938X(03)00014-3

27. S. Skale, V. Doleček, M. Slemnik, Corros. Sci. 2007, 49, 1045-1055. http://dx.doi.org/10.1016/j.corsci.2006.06.027

28. N. A. Swartz, L.T Clare, Electrochim. Acta. 2012, 62, 199-206. http://dx.doi.org/10.1016/j.electacta.2011.12.015

\section{Povzetek}

Zaradi nove direktive, ki omejuje vsebnost hlapnih organskih snovi (HOS) v dekorativnih premazih, so bila razvita alkidna veziva $\mathrm{z}$ visoko vsebnostjo suhe snovi. Zaradi specifične kemijske strukture novih alkidnih veziv z visoko vsebnostjo suhe snovi in posledično spremenjenih aplikativnih lastnosti, je zelo pomembna naloga določitev optimalne kombinacije in koncentracije sušilcev v premazu. Preučevali smo vpliv površinskih sušilcev; Fe sušilca (Fe bispidon) in Co sušilca (Co ethylhexanoate) v kombinaciji z globinskim Sr sušilcem (Sr karboksilat) na sušenje in utrjevanje alkidnih premazov z visoko vsebnostjo suhe snovi. Z infrardečo spektroskopijo s Fourierjevo transformacijo (FT-IR) smo analizirali proces avtooksidacije. Preučevali smo aplikativne lastnosti kot so: čas sušenja in trdoto utrjenega premaznega filma. Z elektrokemično impedančno spektroskopijo (EIS) smo po izpostavi v vlažni komori ovrednotili kvaliteto utrjenega premaznega filma. Raziskava je pokazala, da dodatek Sr sušilca k površinskima sušilcema $(\mathrm{Co}, \mathrm{Fe})$ pospeši avtooksidacijski proces utrjevanja. Z dodatkom višjih koncentracij Sr sušilca so bili končni časi sušenja krajši in vrednosti trdot premaznih filmov višje. Najnižja difuzivnost ionov skozi utrjen premazni film je bila opažena pri kombinaciji Co/Sr in $\mathrm{Fe} / \mathrm{Sr}$ v koncentracijskem razmerju 1:1. 